\title{
Evaluation of colonoscopic findings in patients undergoing colonoscopy due to positive fecal occult blood test: a single center experience
}

\author{
๑T) Tolga Düzenli, @Mevlüt Kiyak \\ Health Sciences University, Sancaktepe Şehit Prof. Dr. İlhan Varank Training and Research Hospital, Department of Gastroenterology, \\ İstanbul, Turkey
}

Cite this article as: Düzenli T, Kiyak M. Evaluation of colonoscopic findings in patients undergoing colonoscopy due to positive fecal occult blood test: a single center experience. J Health Sci Med 2021; 4(5): 646-649.

\begin{abstract}
Aim: Fecal occult blood test is used in the early diagnosis of colorectal cancer. We aimed to evaluate the colonoscopic and pathological findings of patients who underwent colonoscopy due to positive fecal occult blood test in a tertiary center.

Material and Method: Patients who had a positive fecal occult blood test and referred to the Health Sciences University, Sancaktepe Şehit Prof. Dr. İlhan Varank Training and Research Hospital endoscopy unit for colonoscopy were included in this study. Age, gender, colonoscopy findings and pathology results of the patients were recorded. Statistical analyzes were performed with SPSS v21.0.

Results: Two hundred and twenty three patients were included in the current study. Of the patients, 101 (45.3\%) were male and 122 (54.7\%) were female, with a mean age of 53.2 (18-90 years). Endoscopic diagnoses were as 49 (22\%) polyp, 13 (5.8\%) colon cancer, 4 (1.8\%) inflammatory bowel disease, 15 (6.7\%) diverticulum, 63 (28.3\%) perianal disease, 79 (35.4\%) normal colonoscopic findings. Pathological features of colon polyps were as; tubular adenoma in $51 \%$, tubulovillous adenoma in $18.4 \%$, serrated adenoma in $2 \%$, and hyperplastic polyp in $28.6 \%$. Colonoscopic findings of patients according to age groups (over and under 50 years of age); the incidence of polyps $(\mathrm{p}=0.01)$ and diverticulum $(\mathrm{p}=0.001)$ were significantly higher in patients older than 50 years, while perianal diseases $(\mathrm{p}=0.031)$ and normal colonoscopic findings $(\mathrm{p}=0.008)$ were higher in patients younger than 50 years of age.

Conclusion: Colon pathology was detected in approximately $2 / 3$ of the patients presenting with a positive fecal occult blood test. This test is an inexpensive, easily applicable method that helps to detect colon cancer and precursor lesions, as well as pathologies such as subclinical inflammatory bowel disease and diverticulum causing chronic blood loss.
\end{abstract}

Keywords: Fecal occult blood test, colonoscopy, colorectal cancer, polyp

\section{INTRODUCTION}

Colorectal cancers are the third most common cancer in the world and one of the leading causes of cancerrelated deaths (1). Detection of colorectal cancers at an early stage is the most important part of the survival of the disease, allowing curative endoscopic or surgical treatments. With effective screening programs, it may be possible to detect, treat and even prevent the disease in the early period (2).

In Turkey, colon cancer screening program has been carried out since September 2014 by fecal occult blood test (FOBT) every 2 years and colonoscopy every 10 years in healthy individuals aged 50-70 years (3). In addition to that, FOBT is used in the early diagnosis of colorectal cancers all over the world and has been reported to reduce mortality by $25 \%$ (4). Studies pointed out the sensitivity of FOBT between $12.9 \%-79.4 \%$ and the specificity between $86.7 \%$ and $97.7 \%(5)$.

The disadvantages of the FOBT are that it cannot differentiate between upper and lower gastrointestinal bleeding and the test may be affected by diet. On the other hand, FOBT is used in the first place in screening programs in our country because it is easily applicable and cost-effective.

In this study, we aimed to evaluate the colonoscopic and pathological findings of patients who underwent colonoscopy in our hospital due to positive FOBT and to discuss with the literature. 


\section{MATERIAL AND METHOD}

\section{Patient Selection}

Patients who referred to the endoscopy unit of Sancaktepe Şehit Prof. Dr. İlhan Varank Training and Research Hospital for colonoscopy with a positive FOBT between January 2019- June 2021 were included in this study. The study was approved by the Health Sciences University, Sancaktepe Şehit Prof. Dr. İlhan Varank Training and Research Hospital Scientific Research Ethics Committee (Date: 14.07.2021, Decision No: 2021/180) and all procedures were carried out in accordance with the ethical rules and the principles of the Declaration of Helsinki.

Patients with inadequate colon cleansing, active hematochezia, history of colon surgery or inflammatory bowel disease, and those with erosions, ulcers and malignant lesions in the upper gastrointestinal tract were excluded from the study.

Food intake (radish, turnip, broccoli, meat products, cabbage, cauliflower, apple, banana, iron therapy and vitamin $\mathrm{C}$, etc.) that could increase the probability of false positive results was avoided before the test. The stool sample was collected in a clean, lidded container. Patients with diarrhea and women with vaginal bleeding were excluded.

\section{Fecal Occult Blood Test and Colonoscopy}

FOBT was performed with the Guaiac method. Guaiac reaction is a chemical method using indicators such as orthotoluidine, orthodonicidine and benzidine, and can detect bleeding of less than $10 \mathrm{ml}$. Colonoscopies were performed after appropriate preparation and terminal ileum was also evaluated. Biopsy was obtained when there was any pathology and polypectomy was performed if polyp was detected. Age, gender, colonoscopic findings and pathology results of the patients were noted.

\section{Statistical Analysis}

SPSS statistical program version 21.0 (SPSS Inc, Chicago, IL, USA) was used for statistical analysis. Descriptive statistical methods (mean, standard deviation) were used to evaluate study data. Continuous variables were examined with Kolmogorov-Smirnov test for normal distribution. The differences between the two groups were examined with the Mann-Whitney U test or student $T$ test. $\mathrm{p}<0.05$ was considered statistically significant.

\section{RESULTS}

A total of 223 patients were included in the current study. Of the patients, 101 (45.3\%) were male, 122 (54.7\%) were female, with a mean age of 53.2 (18-90 years) (Table 1 ). Endoscopic diagnoses were as; polyps 49 (22\%), colon cancer $13(5.8 \%)$, inflammatory bowel disease $4(1.8 \%)$, diverticulum 15 (6.7\%), perianal disease $63(28.3 \%)$ and normal colonoscopic findings 79 (35.4\%).

\begin{tabular}{|lcc|}
\hline \multicolumn{2}{|l|}{ Table1. Demographic data and colonoscopic findings of patient } \\
group & $\mathbf{n = 2 2 3}$ & $\mathbf{\%}$ \\
\hline & & \\
\hline Gender & 101 & 45.3 \\
Male & 122 & 54.7 \\
Female & & \\
Age, mean & & \\
53.2 (min 18 max 90) & 49 & 22.0 \\
Colonoscopy findings & 13 & 5.8 \\
$\quad$ Polyp & 4 & 1.8 \\
Presence of malignancy & 15 & 6.7 \\
Inflammatory bowel disease & 63 & 28.3 \\
Diverticulum & 79 & 35.4 \\
Perianal disease & & \\
Normal findings & &
\end{tabular}

The pathological features of patients with colon polyps were as tubular adenoma in 51\%, tubulovillous adenoma in $18.4 \%$, serrated adenoma in $2 \%$, and hyperplastic polyp $28.6 \%$.

In terms of dysplasia, $10.2 \%$ of the polyps had high grade and $28.6 \%$ had low grade dysplasia. The localizations of polyps and tumors according to their frequency were as; sigmoid colon $(n=26,41.9 \%)$, transverse colon $(n=10$, $16.1 \%)$, rectum ( $\mathrm{n}=9,14.5 \%)$, ascending colon $(\mathrm{n}=6,9.7 \%)$, descending colon $(n=6,9.7 \%)$ and cecum $(n=5,8.1 \%)$, respectively. There was one polyp in $61.2 \%$, two polyps in $20.4 \%$, three polyps in $6.1 \%$, four polyps in $4.1 \%$, and five or more polyps in $8.2 \%$ of the patients (Table 2).

\begin{tabular}{|lcc|}
\hline \multicolumn{2}{|l|}{ Table 2. Characteristics of colon polyps } & \\
\hline & $\mathbf{n}=\mathbf{4 9 / 2 2 3}$ & $\%$ \\
\hline Pathology of polyp & & \\
$\quad$ Tubular & 25 & 51.0 \\
Tubulovilloz & 9 & 18.4 \\
Serrated & 1 & 2.0 \\
$\quad$ Hyperplastic & 14 & 28.6 \\
Presence of dysplasia & & \\
None & 30 & 61.2 \\
Low grade & 14 & 28.6 \\
High grade & 5 & 10.2 \\
Localization (polyps+tumors) & & \\
Cecum & 5 & 8.1 \\
Ascending colon & 6 & 9.7 \\
Transverse colon & 10 & 16.1 \\
Descending colon & 6 & 9.7 \\
Sigmoid colon & 26 & 41.9 \\
Rectum & 9 & 14.5 \\
Total & 62 & 100.0 \\
The size of the polyp & & \\
$<0,5 \mathrm{~cm}$ & 24 & 49.0 \\
$<1 \mathrm{~cm}$ & 22 & 44.9 \\
$<2 \mathrm{~cm}$ & 1 & 2.0 \\
$<3 \mathrm{~cm}$ & 2 & 4.1 \\
Number of polyps & & \\
1 & 30 & 61.2 \\
2 & 10 & 20.4 \\
3 & 3 & 6.1 \\
4 & 2 & 4.1 \\
$\geq 5$ & & 8.2 \\
\hline
\end{tabular}


When the colonoscopy findings of patients over and less than 50 years of age compared; polyps $(\mathrm{p}=0.01)$ and diverticulum $(\mathrm{p}=0.001)$ were significantly higher in patients over 50 years of age, while perianal diseases $(\mathrm{p}=0.031)$ and normal colonoscopic findings $(\mathrm{p}=0.008)$ were higher in patients younger than 50 years of age (Table 3).

\begin{tabular}{|c|c|c|c|}
\hline & $\begin{array}{c}>50 \text { years } \\
(\mathrm{n}=128, \%)\end{array}$ & $\begin{array}{l}<50 \text { years } \\
(\mathrm{n}=95, \%)\end{array}$ & p \\
\hline Gender & & & 0.273 \\
\hline Male & $62(61.4 \%)$ & $39(38.6 \%)$ & \\
\hline Female & $66(54.1 \%)$ & $56(45.9 \%)$ & \\
\hline Colonoscopy findings & & & $<0.001^{*}$ \\
\hline Polyp & $36(73.5 \%)$ & $13(26.5)$ & $0.01^{*}$ \\
\hline Presence of malignancy & $10(76.9 \%)$ & $3(23.1 \%)$ & 0.142 \\
\hline Inflammatory bowel disease & $2(50 \%)$ & $2(50 \%)$ & 0.763 \\
\hline Diverticulum & $15(100 \%)$ & $0(0 \%)$ & $0.001^{\star}$ \\
\hline Perianal disease & $29(46 \%)$ & $34(54 \%)$ & $0.031^{*}$ \\
\hline Normal findings & $36(45.6 \%)$ & $43(54.4 \%)$ & $0.008^{*}$ \\
\hline
\end{tabular}

\section{DISCUSSION}

FOBT is a test that indicates bleeding originating from any point of the gastrointestinal tract. This test is commonly used to investigate the etiology of anemia or in colon cancer screening programs. Through screening the asymptomatic population; prevention of gastrointestinal cancer, reduction of mortality, radical treatment of precancerous lesions and detection of early-stage cancers can be achieved (6). There are studies showing that mortality and morbidity decrease with colorectal cancer screening programs (7). Although the sensitivity and specificity of the FOBT is not very high, people over 50 years (40 years in some countries) scanned once in a year/ two years, and individuals with a family history of colon cancer have this test done at earlier ages. When FOBT is positive, endoscopic evaluation should be performed.

In the literature, FOBT studies include data from individuals from population-based colon cancer screening programs and mostly reflect the detection rates of precancerous lesions and colorectal cancers. In our study, the FOBT was requested both for the detection of colon cancer and precursor lesions, as well as pathologies leading to chronic blood loss such as subclinical inflammatory bowel disease and diverticulum as an inexpensive, easily applicable method.

Large randomized studies conducted in North America and Western Europe and observational studies from different parts of the world have shown that FOBT reduces mortality of colorectal cancer by $9-32 \%(8)$. In a 14 - year prospective cohort study involving 30.381 patients from Japan, a $44 \%$ decrease in deaths due to colorectal cancers was reported with two or three consecutive FOBT screenings (9). Current guidelines on this subject recommend individuals aged 50-75 years to be screened with FOBT at two-year intervals and with colonoscopy at 10-year intervals (10). On the other hand, there is also evidence showing that screening with FOBT at twoyear intervals has no effect on reducing the incidence of colorectal cancer (8).

In the studies from our country; Utku et al. (7) found 7.5\% colorectal cancer and $26.2 \%$ polyps in the colonoscopy of patients with positive FOBT. Mayir et al. (11) detected $31.5 \%$ adenomatous polyps in screened individuals. Akkuzu et al. (12) reported 5.7\% adeno-carcinoma, $19 \%$ adenomatous polyp, and $1.4 \%$ rectal malignant melanoma in screened patients. In another study in Turkey, precancerous adenomatous polyps were noted as $40 \%$ and colorectal cancer as $4 \%$ in FOBT positive patients (13).

When the localizations of tumors and polyps were examined, more than $50 \%$ of the lesions were detected in the rectum and sigmoid colon. This finding of the current study was compatible with the literature $(8,14-15)$. There are molecular differences between right-sided and leftsided colon tumors and sidedness of the colorectal cancers are important, especially in the metastatic behaviour and in response to anti-EGFR drugs.

One other significant finding of the present study was the high rate of polyps and diverticulum observed in people older than 50 years of age and this outcome was consistent with the literature (16). Potential benefits, potential risks of screening, and available resources should be considered for desicion-making of which age group to screen. For example, because the prevalence of colorectal cancers increase with age, maximum cost-effectiveness can be achieved by screening an older cohort of patients if resources are limited. However, this must be balanced with the number of patients who would be overlooked. Modeling packages were used to balance and analyze these factors. In the US, two modeling tools (MISCAN and SimCRC) were used in 2009 and concluded that screening should be done from age of fifty with annual FOBT and 10-year colonoscopy, or FOBT in 2-3 years plus rectosigmoidesoscopy in 5 years. An analysis including fecal immunochemical test and computed tomography colonoscopy in 2016 investigated the option of a longer screening interval (15 years colonoscopy) combined with an earlier screening start (at 45 years) option, but no significant evidence was found (16). On the other hand, there are also studies stating that the incidence of colorectal cancer increases at younger ages and that screening should be done at earlier ages (17-19). 
In the current study, FOBT was requested in patients younger than 50 years of age with diagnostic indications such as iron deficiency. Perianal diseases and normal colonoscopic findings were found to be significantly higher in this group than the group of over 50 years of age. In a meta-analysis study conducted by Lee et al. (20) it was reported that the sensitivity of FOBT was low in indications other than colorectal cancer screening.

There were limitations in this study. First, it was retrospective. Second, the current study was involving one tertiary center. Prospective, multicenter large cohort studies including FOBT and new methods of colorectal cancer screening are needed to elucidate new perspectives to these methods over population. In this context, there are new methods being investigated for colorectal cancer screening such as analysis of methylated Septin 9 DNA in serum, multitarget-stool DNA or several DNA-RNA or protein markers (8).

\section{CONCLUSION}

Colon pathology was detected in approximately $2 / 3$ of the patients presenting with a positive stool occult blood test. This test is an inexpensive, easily applicable method that helps to detect colon cancer and precursor lesions, as well as pathologies such as subclinical inflammatory bowel disease and diverticulum causing chronic blood loss.

FOBT should be used particularly in the communitybased screening programs of asymptomatic individuals in our country as in European countries, due to its costeffectiveness and easy access. However, when considered on an individual case to case basis, a negative FOBT should not interfere with colonoscopy screening

\section{ETHICAL DECLARATIONS}

Ethics Committee Approval: The study was approved by the Health Sciences University, Sancaktepe Şehit Prof. Dr. İlhan Varank Training and Research Hospital Scientific Research Ethics Committee (Date: 14.07.2021, Decision No: 2021/180).

Informed Consent: Because the study was designed retrospectively, no written informed consent form was obtained from patients.

Referee Evaluation Process: Externally peer-reviewed.

Conflict of Interest Statement: The authors have no conflicts of interest to declare.

Financial Disclosure: The authors declared that this study has received no financial support.

Author Contributions: All of the authors declare that they have all participated in the design, execution, and analysis of the paper, and that they have approved the final version.

\section{REFERENCES}

1. Xi Y, Xu P. Global colorectal cancer burden in 2020 and projections to 2040. Transl Oncol 2021; 14: 101174.

2. Dekker E, Tanis PJ, Vleugels JLA, Kasi PM, Wallace MB. Colorectal cancer. Lancet 2019; 394: 1467-80.

3. TC SB Halk Sağlığı Genel Müdürlüğü Kolorektal Kanser Tarama Programı Ulusal Standartları. https://hsgm.saglik.gov.tr/tr/ kanser-tarama-standartlari/listesi/kolorektal-kanser-taramaprogram $\%$ C4\%B1-ulusal-standartlar\%C4\%B1.html (access date: 08.08.2021)

4. Bretthauer M. Evidence for colorectal cancer screening. Best Pract Res Clin Anaesthesiol 2010; 24: 417-25.

5. Lieberman DA. Clinical practice. Screening for colorectal cancer. N Engl J Med 2009; 361: 1179-87.

6. Kara M, Tanoglu A. Screening strategies in a global public health issue colorectal carcinoma and place of colonoscopy. TAF Prev Med Bull 2013; 12: 743-50.

7. Utku OG, Ergul B, Oguz D. Gaitada gizli kan testi pozitifliği nedeni ile kolonoskopi yapılan hastaların kolonoskopik ve patolojik sonuçlarının değerlendirilmesi. Akademik Gastroenteroloji Derg 2018; 17: 17-20.

8. Lauby-Secretan B, Vilahur N, Bianchini F, et al. The IARC perspective on colorectal cancer screening. N Engl J Med 2018; 378: 1734-40.

9. Tanaka K, Sobue T, Zha L, et al. Effectiveness of screening using fecal occult blood test and colonoscopy on the risk of colorectal cancer: The Japan Public Health Center-based prospective study. J Epidemiol 2021; 10.2188/jea.JE20210057.

10. Qaseem A, Crandall CJ, Mustafa RA, et al. Screening for colorectal cancer in asymptomatic average-risk adults: a guidance statement from the American College of Physicians. Ann Intern Med 2019; 171: 643-54.

11. Mayir B, Ensari CÖ, Durhan A, Çöpelci Y. Kolorektal kanser tarama amaçlı yapılan gaytada gizli kan testi pozitif saptanan hastalarda kolonoskopi bulguları. Turk J Colorectal Dis 2018; 28: 27-30.

12. Akkuzu MZ, Sezgin O, Üçbilek E, et al. Gaitada gizli kan pozitifliği nedeniyle kolonoskopi yapılanlarda kolorektal malignite sıklığı. MKÜ Tip Derg 2020; 11: 109-12.

13. Kara Y, Sarıcı İş, Kalaycı MU. Bölgemizde yürütülen kolon kanser tarama programının etkinliğinin değerlendirilmesi. İstanbul Kanuni Sultan Süleyman Tip Derg 2019; 11: 31-6.

14. Hultcrantz R. Aspects of colorectal cancer screening, methods, age and gender. J Intern Med 2021; 289: 493-507.

15. Kamis F, Tanoglu A, Unal Cetin E, Beyazit Y, YazganY. Retrospective analysis of patients underwent colonoscopic polypectomy: A two-center study. Med Sc 2020; 9: 473-7.

16. Bevan R, Rutter MD. Colorectal cancer screening-who, how, and when? Clin Endosc 2018; 51: 37-49.

17. Siegel RL, Fedewa SA, Anderson WF, et al. Colorectal cancer incidence patterns in the United States, 1974-2013. J Natl Cancer Inst 2017; 109: djw322.

18. Vuik FE, Nieuwenburg SA, Bardou M, et al. Increasing incidence of colorectal cancer in young adults in Europe over the last 25 years. Gut 2019; 68: 1820-6.

19. Saad El Din K, Loree JM, Sayre EC, et al. Trends in the epidemiology of young-onset colorectal cancer: a worldwide systematic review. BMC Cancer 2020; 20: 288.

20. Lee MW, Pourmorady JS, Laine L. Use of fecal occult blood testing as a diagnostic tool for clinical indications: a systematic review and meta-analysis. Am J Gastroenterol 2020; 115: 662-70. 